\title{
Cardanol: a Promising Building Block for Biobased Polymers and Additives
}

Sylvain Caillol ${ }^{\mathrm{a}^{*}}$

a ICGM UMR 5253 - CNRS, ENSCM, Université de Montpellier, 240 Av Prof Emile Jeanbrau, Montpellier, France.

* Corresponding author. E-mail sylvain.caillol@enscm.fr. Telephone +33467144327.

\section{Abstract}

Among the renewable resource materials, cashew nut shell liquid (CNSL) is considered as an important starting material due to its unique structural features, abundant availability and low cost. A large number of chemicals and products have been developed starting from CNSL by taking advantage of the three reactive sites, namely, phenolic hydroxyl, aromatic ring and unsaturation(s) in the alkenyl side chain. Increasing attention is paid to promising cardanol-based products that could be have potential interest in industry, such as epoxy and acrylic monomers, plasticizers and surfactants.

\section{Keywords}

Cardanol; cashew nut shell liquid; epoxy; acrylate; surfactant; plasticizer

\section{Highlight}

This report describes a cardanol-derived chemical platform for the synthesis of various reactive building blocks dedicated to the synthesis of polymers that may be applied for polyepoxides, polyacrylates, plasticizers and surfactants.

\section{Introduction}

The chemistry of the renewable resources applied to the production of commercial products represents a very important topic, and has captured the attention both academic and industrial communities. In the past few years, the synthesis of monomers, polymers, and additives starting from renewable resources gained increased attention. Recent efforts react to the volatility of prices of petro-chemical products associated with growing environmental concerns. The most widely used renewable raw materials include: wood, proteins, cellulose, lignin, tannins, starch, vegetable oils, animal resources like chitin and chitosan, etc. [1-5]

Vegetable oils such as soybean, tung, linseed, rapeseed or castor oils have a wide variety of applications [6,7]. Among these, cashew nut shell liquid (CNSL), an agricultural byproduct abundantly available in many parts of the world, is unique because it contains a 
phenolic moiety with an unsaturated 15-carbon side chain [8-10]. CNSL being a non-edible oil, does not potentially put undue pressure on the food supply chain unlike other renewable (edible) chemical feed-stocks. CNSL can potentially replace phenol in many applications with equivalent or better results. Greater utilization of CNSL as a starting material for industrial polymer products can be an attractive proposal in view of its low cost, abundant availability, and chemically reactive nature, amongst other attributes [11].

Several reviews have appeared, on various domains of cardanol chemistry, summarizing the composition, the production, the reactions or applications of CNSL [12-24]. This review deals only with the most promising aspects of CNSL chemistry which could allow its broad application in industry. It includes the functionalization of cardanol, the synthesis of valuable monomers, polymers, and additives and their properties.

\section{Cardanol}

Cardanol is produced from cashew nut shell liquid (CNSL). This CNLS is directly extracted from the shell of the cashew nut, fruit of the cashew tree, Anacardium occidentale, mostly grown in India, East Africa and Brazil [25]. The global production of CNSL approaches one million tons annually [26]. Hence, CNSL became one of the few major and economic sources of naturally occurring phenols. This really promising aromatic renewable source represents a promising natural alternative to petroleum derived phenols [27]. If the production of petroleum derived phenol reaches roughly 90 million tons annually, the comparatively small volumes of CNSL suggest of course that at least initially, niche market should be addressed as deployment targets. CNSL constitutes approximately $25 \%$ of the total weight of the cashew nut. CNSL is composed of anacardic acid (3- $n$-pentadecylsalicylic acid) and smaller amounts of cardanol (3-n-pentadecylphenol), cardol (5- $n$ pentadecylresorcinol), and methylcardol (2-methyl-5-n-pentadecylresorcinol). The long aliphatic side-chain being of cardanol are saturated, mono-olefinic $(8)$, di-olefinic $(8,11)$, and tri-olefinic $(8,11,14)$ with an average value of two double bonds per molecule (Figure 1$)$. The thermal treatment of CNSL followed by a distillation lead to the decarboxylation of anacardic acid that yields an industrial grade of cardanol (about 90\% purity), with a small quantity of cardol and methylcardol [28, 29]. Cardanol is a yellow pale liquid comprising four meta-alkyl phenols differing by the degree of unsaturation of the aliphatic chain: saturated chains (SC) 8.4\%, monoolefinic (MO) 48.5\%, diolefinic (DO) $16.8 \%$ and triolefinic (TO) $29.33 \%$ chains $[30,31]$. 
<smiles>[R]c1cccc(O)c1C(=O)O</smiles>

Anacardic Acid $74-77 \%$<smiles>[R]c1cccc(O)c1</smiles>

Cardanol $1-9 \%$<smiles>[R]c1cc(O)cc(O)c1</smiles>

Cardol $15-20 \%$<smiles>[R]c1cc(O)c(C)c(O)c1</smiles>

2-methyl cardol $1-3 \%$<smiles>[R]C1CCC(CC)CC1[R]</smiles>

Saturated $(5-8 \%)$

Monoene (48-49\%)

Diene (16-17\%)

Triene (29-30\%)

Figure 1: Components of CNSL

\section{Functionalization of Cardanol}

During the extraction or refining processes, anacardic acid decarboxylates to cardanol upon heating (Scheme 1, a). Distillation of the crude CNSL also leads to decarboxylation as the distillate is found to contain mainly cardanol. [32] Hydrogenation (Scheme 1, b) is generally carried out using hydrogen and catalysts such as copper chromite, nickel, palladium or platinum. [33] Hydrogenated cardanol can be separated by distillation, as is done with crude CNSL (Scheme 1). Perdriau et al. [34] carried out an interesting conversion of polyenes of CNSL to monoenes by $\mathrm{RuCl}_{3}$-catalyzed transfer hydrogenation.

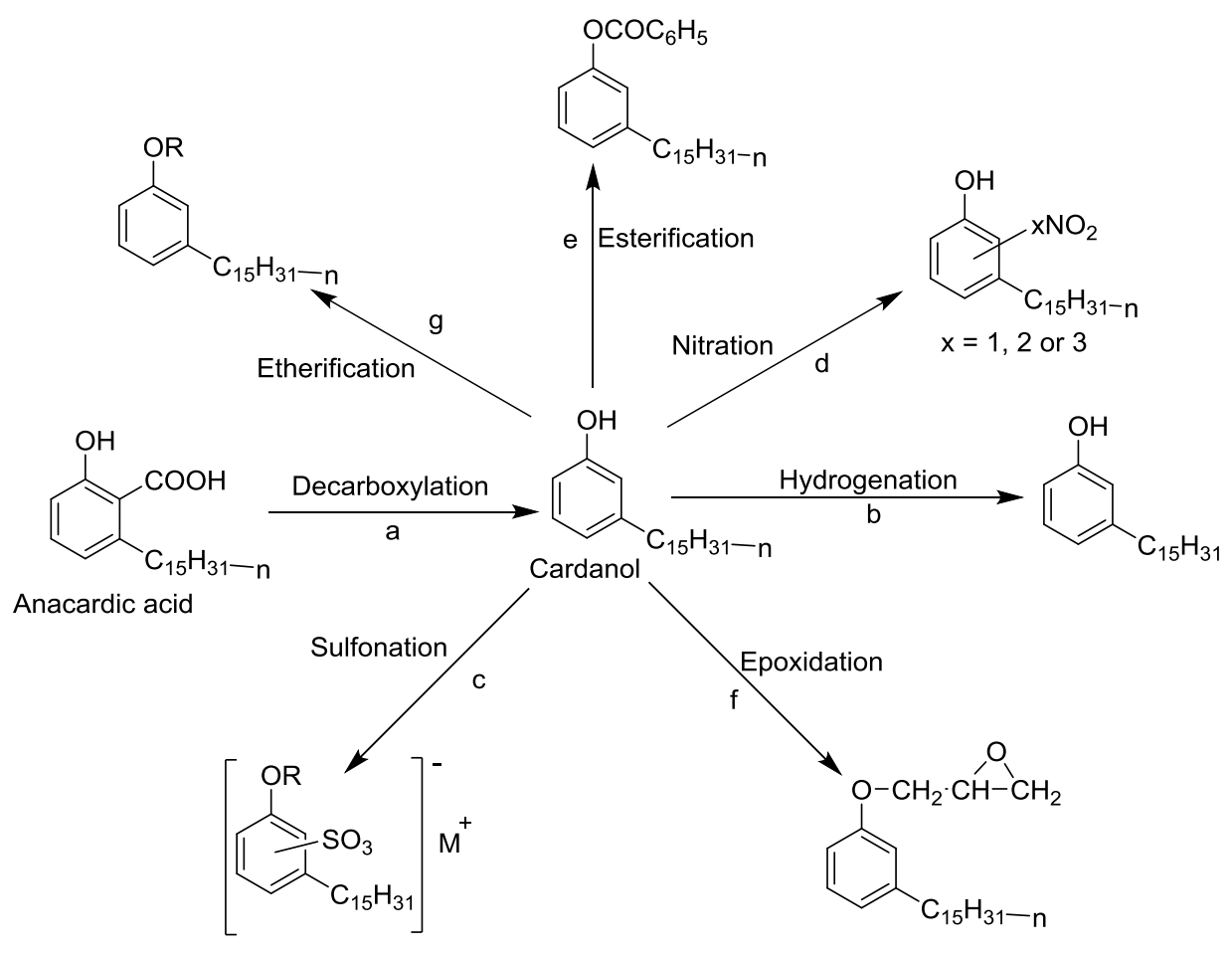

Scheme 1: Reaction products of cardanol

CNSL derivatives can be sulfonated to yield alkyl aryl sulfonic acid or their metal salts (Scheme 1, c).[13, 35] Direct nitration of hydrogenated cardanol gives the nitro-derivatives 
(Scheme 1, d). [36] Halogenation of CNSL can be accomplished with comparative ease. For example, chlorine gas can be passed through CNSL dissolved in kerosene to obtain $15 \%$ (w/w) chlorination. [37] Cardanol reacts with acid chlorides in the presence of alkali or base to give the corresponding cardanyl esters (Scheme 1, e). [38] Epoxidation of cardanol (Scheme 1, f) can be accomplished by using epichlorohydrin in the presence of caustic soda as a catalyst. [39, 40] Etherification was also reported with various alkyl halides (Scheme 1, g). $[13,34]$ Hence, a variety of techniques can be used to functionalize CNSL into reactive building blocks or additives.

\section{Polyepoxide networks}

Polyepoxide networks are a major class of thermoset polymers, with a global production around 2Mt/y [41]. Polyepoxide polymers are extensively used as coatings, adhesives and in structural applications owing to their outstanding mechanical and electrical properties, chemical resistance and adhesion. Diglycidyl ether of Bisphenol A (DGEBA) is nowadays the most used monomer for the synthesis of epoxy polymers and materials. DGEBA is synthesized by epoxy-functionalization of bisphenol A (BPA). Indeed, the aromatic ring of BPA is particularly interesting since it confers good thermal, chemical and mechanical resistance to epoxy polymers. However, this compound has estrogen-like activity and acts as an endocrine disruptor. It mimics the body's own hormones and may lead to several negative health effects [42-44]. The negative impact of BPA on human health and the environment necessarily implies the elimination of BPA especially in food contact materials. Therefore there is an increasing interest within the chemical industry for non-harmful aromatic substituents to BPA, especially for the synthesis of epoxy polymers. Thus, cardanol could be an interesting substitute to BPA in some polymers such as epoxy polymers.

Hence, the phenolic function of cardanol was reacted with epichlorohydrin $[45,46]$ under basic conditions, with $\mathrm{ZnCl}_{2}$, at $95{ }^{\circ} \mathrm{C}$. This product is commercialized by the Cardolite Coporation. A patent also claims the use of commercial epoxidized cardanol [47]. Furthermore, the epoxidation of double bonds of cardanol was also carried out with perbenzoic acid by Greco et al. [48] and Patel et al. [49]. Suresh [50] performed this reaction with performic acid. Moreover, the epoxidation of these double bonds could also be performed with enzymes such as Candida Antarctica lipase (yield 95\%) [51]. Additionally, polyepoxy cardanol was synthesized by direct polymerization of double bonds of epoxidized cardanol followed by reaction with various amines [52]. Our team particularly studied the synthesis of new cardanol based epoxy monomers and the formulation of epoxy networks. [53-57] We demonstrated the promising properties of cadanol polyepoxide networks that could meet some expected properties of classic polyepoxide materials. Hence, the polymers synthesized with epoxidized cardanol Cardolite NC-514 exhibit lower $\mathrm{Tg}$ values than with 
DGEBA, due to the long aliphatic chain of cardanol but very interesting thermal stabilities. The mechanical properties for NC-514 epoxies are lower than for DGEBA epoxies however the moduli recorded could be interesting for coating applications.

\section{From radical polymerization to latex}

Even if cardanol bears double bonds poorly reactive in radical polymerization, the interest in radical polymerization to lead to low $\mathrm{Tg}$ polymers for coatings and binders is very attractive. Unmodified cardanol was used directly as a comonomer in the suspension polymerization of MMA or styrene which limits its copolymerization [58]. Finally, cardanyl acrylate and methacrylate were polymerized in solution using conventional polymerization and ATRP [59-61]. To the best of our knowledge, there is only one report describing the use of cardanyl acrylate in homopolymerization or copolymerization with methyl methacrylate or styrene under suspension polymerization conditions [62] and the use of unmodified cardanol in emulsion polymerization [63] (Scheme 2).

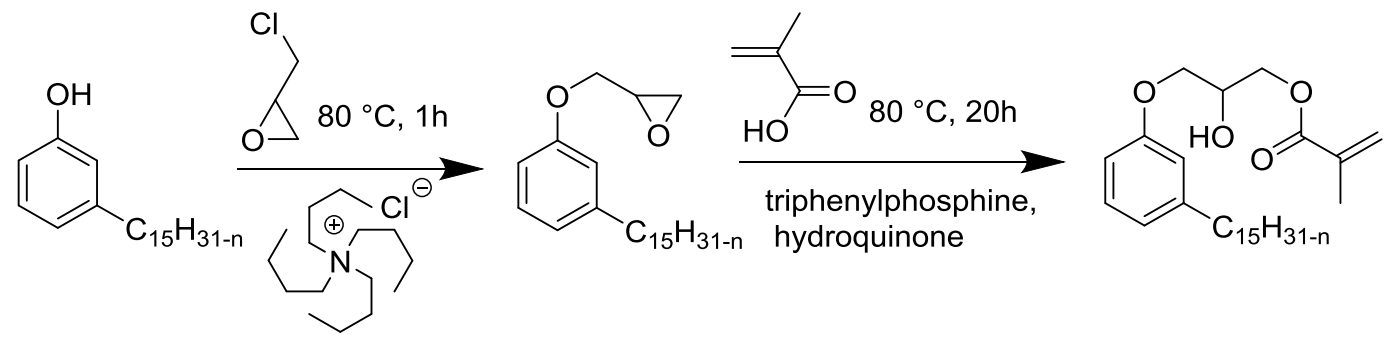

Scheme 2: Synthesis of the cardanol methacrylate monomer

We functionalized cardanol into methacrylated cardanol and studied homopolymerization and copolymerization with methyl methacrylate in emulsion polymerization. We also proposed the feasibility of coating application with UV crosslinking via thiol-ene chemistry. The cross-linked coating exhibit promising thermal and mechanical resistance properties, opening the route to the development of new cardanol emulsion polymers [64].

\section{Plasticizing agents}

It is expected that PVC annual production reaches 59 million tons in 2020. [6567] The applications extend from highly rigid PVC to flexible PVC using plasticizers with a mass ratio ranging from 30 to $50 \%$. It has been established that cardanol, when used as a plasticizer for poly(vinyl chloride) (PVC), gives rise to similar tensile properties, shorter cure times, and superior ageing behavior compared to aromatic oil, 
a conventional plasticizer.[68] Cardanol presents chemical and physical properties very close to those of diisononyl phthalate (DINP) or di(2-ethylhexyl)phthalate (DEHP). Thanks to their low cost and good performances with PVC, these additives are produced in large quantities. However, reprotoxicity of phthalates on both animals and humans is reported [69-75] and some of them were recently banned by DCE and $\mathrm{REACH}$ regulations in Europe.

In the last ten years, many studies have been focused on the synthesis of cardanol-based PVC plasticizers. Indeed, due to its aromatic groups bringing thermal stability and its $\mathrm{C} 15$ alkyl chain that could confer a plasticizing effect, cardanol can be considered as a promising substituent to phthalates. Esterified cardanols by short alkyl chains have already shown good results as secondary plasticizers in presence of DEHP [76-77]. Epoxidation of double bonds improves the plasticizing properties and the thermal stability of PVC as previously demonstrated on esterified cardanol bearing short alkyl chain (i.e. acetate) and used as an efficient primary plasticizer [78].

\section{Surfactants}

CNSL has been examined previously as a starting material for various classes of surfactants, such as cationic compounds [79, 80], non-ionic [81, 82] and anionic compounds (Figure 2, S1-S9).[83-85] It is reported that saturated cardanol is readily sulfonated with excess sulfuric acid in halogenated solvents at ambient temperature (Figure 2, S3-S4).[86-88, 102-104] It has been demonstrated that CNSL and saturated CNSL upon reaction with ethylene sulfate gave sulfo derivatives which possess excellent surfactant properties.[89] The use of ethylene sulfate with the phenoxide is an improvement which avoids both the reaction with sulfuric acid and the need for an initial hydroxyethylation step. In recent years, several amphiphilic molecules based on cardanol have been investigated and found to be potentially useful for many industrial applications (Figure 2, S5) [90-93]

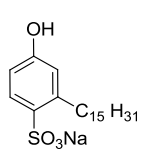

$\mathrm{S} 1$

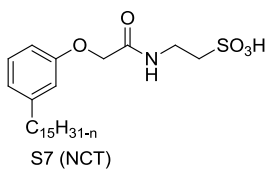

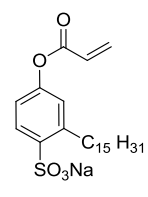

S3

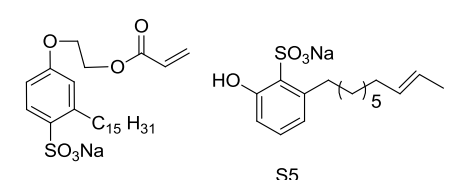

$\mathrm{S} 4$

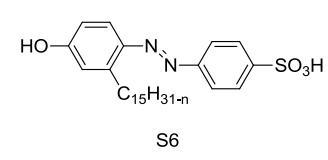

s6
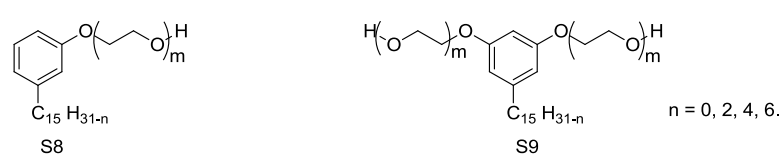

Figure 2: Selected CNSL-based surfactants 
Peungjitton et al. [35] synthesized sodium cardanol sulfonate surfactant from cardanol (Figure 2, S1). The surfactant properties of cardanol sulfonate were compared with dodecylbenzene sulfonate and were found to be similar; therefore, cardanol sulfonate may be used as a raw material for commercial detergent production. Cardanol sulfonate may probably be produced on an industrial scale because the production process of cardanol sulfonate is simple as there is no difficult step of alkylation of benzene before sulfonation as with common alkylbenzene sulfonates. Also, production of cardanol sulfonate on an industrial scale is potentially of low cost in comparison with the production of common detergents. Effective nonionic, anionic and cationic surfactants based on cardanol are described in the literature, however, only one article reports the synthesis of a zwitterionic surfactant from cardanol [94]. Zwitterionic surfactants have excellent surface and interface proprieties, low irritation, good detergency and high stability. Their solubility is less affected by $\mathrm{pH}$ than anionic and cationic surfactants. Zwitterionic sulfobetaine surfactants have good compatibility and synergy with anionic surfactant [95, 96]. In addition, zwitterionic betaine surfactant has excellent performance for Enhanced Oil Recovery [97].

\section{Conclusion}

Cardanol, a major constituent of CNSL which is a by-product of cashew industry, is a cheap, and abundantly available versatile industrial raw material of great promise for the replacement of certain products based on fossil resources. The presence of phenolic hydroxyl group and olefinic linkages in the C15 alkyl chain, combined with the aromatic ring makes cardanol an interesting starting material for the synthesis of various value added products by making use of reactivity of each of these functionalities. Hence, dynamic research is developed by several academic teams [98]. In industry, Cardolite has a leading position with various commercial products [99, 100]. Currently, the most promising products from cardanol are epoxy monomers, acrylate, PVC-plasticizers and emulsion surfactants. But very interesting development gain attention, such as the work of Lemaire et al. who succeeded in the synthesis of 3-pentadecylcyclohexanone, which has structural similarity with the cyclohexanone, a very important building block of the petro-based chemical industry [101]. Thus, we could consider that CNSL-based products would find widespread applications especially for the production of polymers with a unique combination of properties.

\section{References}


[1] L. M. de Espinosa and M. A. R. Meier, Eur. Polym. J., 2011, 47, 837-852.

[2] J. Zakzeski, P. C. A. Bruijnincx, A. L. Jongerius and B. M. Weckhuysen, Chem. Rev., 2010, 110, 3552-3599.

[3] G. W. Huber, S. Iborra and A. Corma, Chem. Rev., 2006, 106, 4044.

[4] A. Demirbas, Energy Convers. Manage., 2009, 50, 2782-2801.

[5] G. A. Olah, Angew. Chem., Int. Ed., 2005, 44, 2636-2639.

[6] U. Biermann, U. Bornscheuer, M. A. R. Meier, J. O. Metzger and H. J. Schafer, Angew. Chem. Int. Ed., 2011, 50, 3854-3871.

[7] E. D. Rio, G. Lligadas, J.C. Ronda, M. Galia, M.A.R. Meier and V. Cadiz, J. Polym. Sci. Part A: Polym. Chem., 2011, 49, 518-525.

[8] C. K. S. Pillai, Des. Monomers Polym., 2010, 13, 87-121.

[9] R. Paramashivappa, P. P. Kumar, P. J. Vithayathil and A. S. Rao, J. Agric. Food Chem., 2001, 49, 2548- 2551.

[10] P. Blazdell, Int. Sci. Rev., 2000, 28, 220-226.

[11] A. Velmurugan and M. Loganathan, World Acad. Sci. Eng. Technol., 2011, 58, 889-894.

[12]V. S. Balachandran, S. R. Jadhav, P. K. Vemula and G. John, Chem. Soc. Rev., 2013, 42, 427-438.

[13] M. C. Lubi and E. T. Thachil, Des. Monomers Polym., 2000, 3, 123-153.

[14] C. K. S. Pillai, Pure Appl. Chem., 1998, 70, 1249-1252.

[15] P. H. Gedam and P. S. Sampathkumaran, Prog. Org. Coat., 1986, 14, 115-157.

[16] (**) D Chatterjee, N V. Sadavarte, R D. Shingte, A. S. More, B. V. Tawade, A. D. Kulkarni, A. B. Ichake, C. V. Avadhani, P. P. Wadgaonkar, (2017) Step-Growth Polymers from Cashew Nut Shell Liquid (CNSL)-Based Aromatic Difunctional Monomers. In: Anilkumar P. (eds) Cashew Nut Shell Liquid. Springer, Cham

[17] A. Kozubek, J. H. P. Tyman and R. Atta-Ur, Stud. Nat. Prod. Chem., 2005, 30, 111-190.

[18] G. Mele and G. Vasapollo, Mini-Rev. Org. Chem., 2008, 5, 243-253.

[19] P. L. Nayak, J. Macromol. Sci. Part C: Polym. Rev., 2000, 40, 1-21.

[20] J. M. Raquez, M. Deleglise, M. F. Lacrampe and P. Krawczak, Prog. Polym. Sci., 2010, 35, 487-509.

[21] R. Saladino, G. Gualandi, A. Farina, C. Crestini, L. Nencioni and A. T. Palamara, Curr. Med. Chem., 2008, 15, 1500-1519.

[22] G. Vasapollo, G. Mele and R. Del Sole, Molecules, 2011, 16, 6871-6882.

[23] P. K. Vemula and G. John, Acc. Chem. Res., 2008, 41, 769-782.

[24] C. Voirin, S. Caillol, N. V. Sadavarte, B., V. Tawade, B. Boutevin and P. P Wadgaonkar, Polymer Chemistry, 2014, 5, 3142-3162

[25] Ionescu M., Wan X., Biliç N., Petrović ZS., J. Pol. Env., 2012, 20, 647-658

[26] Campaner, Pietro; D'Amico, Daniele; Longo, Luigia; Stifani, Cristina; Tarzia, Antonella, J. Appl. Pol. Sci., 2009, 114, 3585-3591

[27] Pillai, CKS ; Prasad, VS ; Sudha, JD ; Bera, SC ; Menon ARR, J. Appl. Pol. Sci., 1990, 41,2487

[28] Phani Kumar P., Paramashivappa R., Vithayathil PJ., Subba Rao PV., Srinivasa R., J. Agric. Food Chem.; 2002, 50, 4705-4708

[29] Carioca JOB., Vasconcelos GFC., Abreu RF., Monteiro A., CTF, 2nd Mercosur Congress on Chemical Engineering, 2005, Brazil

[30] Sultania M., Rai JSP., Srivastava D., J. Haz. Mat., 2011, 185, 1198-1204

[31] Tyman JHP, J. Chromato., 1975, 111, 277-284

[32] P. K. Jain and K. J. Sivala, Food Engg., 1997, 32, 339-345.

[33] T. Gandhi, M. Patel and B. K. Dholakiya, J. Nat. Prod.Plant Resour., 2012, 2, 135-142.

[34] S. Perdriau, S. Harder, H. J. Heeres and J. G. de Vries, ChemSusChem, 2012, 5, 2427 2434. 
[35] Peungjitton, P. Sangvanich, S. Pornpakakul, A. Petsom and S. Roengsumran, J. Surfact. Deterg., 2009, 12, 85-89.

[36] O. A. Attanasi, S. Berreta, C. Fiani, P. Fillippone, G. Mele and R. Saladino, Tetrahedron, 2006, 62, 6113-6120.

[37] O. A. Attanasi, S. Berreta and P. Filippone, Org. Prep. Proc. Int., 1995, 27, 645-653.

[38] H. P. Bhunia, A. Basak, T. K. Chaki and G. B. Nando, Eur. Polym. J., 2000, 36, $1157-$ 1165 .

[39] K. P. Unnikrishnan and E. T. Thachil, Des. Monomers Polym., 2008, 11, 593-607.

[40] Y. H. Kim, E. S. An, S. Y. Park and B. K.Song, J. Mol. Catal. B, 2007, 45, 39-44.

[41] Shen L, Haufe J, Patel MK. Product overview and market projection of emerging biobased plastics, Utrecht University commissioned by European Polysaccharide network of excellence and European bioplastics 2009.

[42] O’Connor JC., Chapin RE., Pure. Appl. Chem., 2003; 75, 2099-2123.

[43] Okada H., Tokunaga T., Liu X., Takayanagi S., Matsushima A., Shimohigashi Y., Enviro. Health. Persp. 2008, 116, 32-38.

[44] Vom Saal FS, Myers JP., J. Am. Med. Assn., 2008, 300, 1353-1355.

[45] Verneker SP., No Title, Ind. J. Tech., 1980, 18, 170

[46] Baker NF., Epoxy resin compositions, U.S. Patent 824 302, 1955.

[47] Agarwal RK., Bammel BD., Fristad WE., Rossier GW., Siebert EJ., Yang Z., US Patent $0104212,2003$.

[48] Greco A., Brunetti D., Renna G., Mele G., Maffezzoli A., Pol. Degrad. Stab., 2010, 95, 2169-2174.

[49] Patel MB., Patel RG., Patel VS., J. Therm. Anal., 1989, 35, 47-57

[50] Suresh KI., ACS Sustainable Chemistry \& Engineering, 2013, 1, 232-242.

[51] Kim YH., An ES., Park SY., Song BK., J. Macromol. Cat. B : Enzymatic, 2007, 45, 3944

[52] Kanehashi S., Yokoyama K., Masuda R., Kidesaki T., Nagai Kazukiyo, Miyakoshi T., J. Appl. Pol. Sci., 2013, 130, 2468-2478

[53] F. Jaillet, E. Darroman, A. Ratsimihety, R. Auvergne, B. Boutevin, S. Caillol, European Journal of Lipid Science and Technology, 2013, 116, 63-73

[54] E. Darroman, L. Bonnot, R. Auvergne, B. Boutevin, S. Caillol, European Journal of Lipid Science and Technology, 2014, 117, 178-189

[55] E. Darroman, N. Durand, B. Boutevin, S. Caillol, Progress in Organic Coatings, 2015, $83,47-54$

[56] S. Dworakowska, A. Cornille, D. Bogdał, B. Boutevin, S. Caillol, European Journal of Lipid Science and Technology, 2015, 117, 1893-1902

[57] (*) Emilie Darroman, Nelly Durand, Bernard Boutevin, Sylvain Caillol*, Progress in Organic Coatings, 2016, 91, 9-16

This is an interesting article that reports routes to use cardanol in formulations in order to replace Bisphenol A in polyepoxide networks

[58] Moreno M., Goikoetxea M., de la Cal J., Barandiaran M., J. Pol. Sci, Part A: Pol. Chem. $2014,52,3543$.

[59] Moreno M, Miranda J, Goikoetxea M, Barandiaran M, Sustainable polymer latexes based on linoleic acid for coatings applications Progress in Organic Coatings, 2014, 77, 1709-1714

[60] Ugelstad, J.; El-Aasser, M. S.; Vanderhoff, J. W. J. Polym. Sci. Polym. Lett. Ed. 1997, $11,503$.

[61] Landfester, K. Macromol. Rapid Commun. 2001, 22, 896.

[62] Asua, J. M. Prog. Polym. Sci. 2002, 27, 1283.

[63] Quintero, C.; Mendon, S. K.; Smith, O. W.; Thames, S. F. Prog. Org. Coat. 2006, 57, 195. 
[64] (**) V. Ladmiral, R. Jeannin, K. Fernandes Lizarazu, J. Lai-Kee-Him, P. Bron, P. Lacroix-Desmazes and S. Caillol, European Polymer Journal, 2017, 93, 785-794

[65] P. Persico, V. Ambrogi, D. Acierno, C. Carfagna, J. Vinyl Addit. Technol. 15, 2009, 139-146.

[66] J. Chen, Z. Liu, J. Jiang, X. Nie, Y. Zhou, R.E. Murray, RSC Adv. 5, 2015, 5617156180.

[67] R. Navarro, M.P. Perrino, M.G. Tardajos, H. Reinecke, Macromolecules 43, 2010, $2377-$ 2381.

[68] M. Alexander and E. T. Thachil, J. Appl. Polym. Sci., 2006, 102, 4835-4841.

[69] Koch, H. M.; Bolt, H. M.; Angerer, J. Arch. Toxicol. 2004, 78, 123.

[70] Sampson, J.; De Korte, D. Transfus. Med. 2011, 21, 73.

[71] Becker, K.; Seiwert, M.; Angerer, J.; Heger, W.; Koch, H. M.; Nagorka, R.; Roßkamp, E.; Schleuter, C.; Seifert, B.; Ullrich, D. Int. J. Hyg. Heal. 2004, 207, 409.

[72] Hill, S. S.; Shaw, B. R.; Wu, A. H. Clin. Chim. Acta 2001, 304, 1.

[73] J. Choi, S. Kwak, Environ. Sci. Technol. 41, 2007, 3763-3768.

[74] T. Mekonnen, P. Mussone, H. Khalil, D. Bressler, J. Mater. Chem. A 1, 2013, 1337913398.

[75] P. Jia, M. Zhang, C. Liu, L. Hu, G. Feng, C. Bo, Y. Zhou, RSC Adv. 5, 2015, 41169e41178

[76] Greco, A.; Brunetti, D.; Renna, G.; Mele, G.; Maffezzoli, A.Polym. Degrad. Stab. 2010, 95, 2169.

[77] Yang. P,Jun Yan. J, Sun. H, Fan. H, Chen. Y, Wang. F, Shi.B, RSC Adv., 2015, 5, 16980

[78] Greco, A.; Ferrari, F; Maffezzoli, A.Polym. Degrad. Stab. 2016, 10, 010.

[79] J. H. P. Tyman, Chem. Soc. Rev., 1979, 8, 500-538.

[80] J. H. P. Tyman and M. Patel, J. Chem. Res., 2007,1, 34-37.

[81] J. H. P. Tyman and I. E. Bruce, J. Surfact. Deterg., 2003, 6, 291-297.

[82] J. H. P. Tyman and I. E. Bruce, J. Surfact. Deterg., 2004, 7, 167-173.

[83] C. Cheng, X. Bai, S. Liu, Q. Huang, Y. Tu, H. Wu and X. Wang, J. Polym. Res., 2013, 20, 1-11.

[84] C. Scorzza, J. Nieves, F. Vejar and J. Bullon, J. Surfact. Deterg., 2010, 13, 27-31.

[85] S. C. Sethi, B. C. Subba Rao, S. H. Kulkarni and S. S. Katti, Ind. J. Tech., 1963, 1, 348355.

[86] J. A. Mmongoyo, Q. A. Mgani, S. J. M. Mdachi, P. J. Pogorzelec and D. J. ColeHamilton, Eur. J. Lipid Sci. Tech., 2012, 114, 1183-1192.

[87] S. Kattimuttathu, G. Foerst, R. Schubert and E. Bartsch, J. Surfact. Deterg., 2012, 15, 207-215.

[88] I. E. Bruce, L. Mehta, M. J. Porter, B. K. Stein and J. H. P. Tyman, J. Surfact. Deterg., 2009, 12, 337-344.

[89] M. J. Antony and M. Jayakannan, J. Phys. Chem. B, 2007, 111, 12772-12780.

[90] P. Anilkumar and M. Jayakannan, J. Phys. Chem. C, 2007, 111, 3591-3600.

[91] P. Anilkumar and M. Jayakannan, J. Phys. Chem. B, 2009, 113, 11614-11624.

[92] J. H. Jung, G. John, K. Yoshida and T. Shimizu, J. Am. Chem. Soc., 2002, 124, 1067410675.

[93] P. Anilkumar and M. Jayakannan, Langmuir, 2006, 22, 5952-5957.

[94] I. Faye, V. Besse, G. David, S. Caillol; Green Materials, 2017, 5, 144-152

[95] McLachlan, A. A.; Marangoni, D. G., Interactions between zwitterionic and conventional anionic and cationic surfactants. J Colloid Interf Sci 2006, 295, (1), 243-248.

[96] Munoz, M.; Rodriguez, A.; Graciani, M. D.; Moya, M. L., Conductometric, surface tension, and kinetic studies in mixed SDS-Tween 20 and SDS-SB3-12 micellar solutions. Langmuir 2004, 20, (25), 10858-10867. 
[97] Liu, Q.; Dong, M. Z.; Ma, S. Z.; Tu, Y., Surfactant enhanced alkaline flooding for Western Canadian heavy oil recovery. Colloid Surface A 2007, 293, (1-3), 63-71.

[98] B V. Tawade, J K. Salunke, P S. Sane, P P. Wadgaonkar, Journal of Polymer Research, 2014, 21:617

[99] (*) P Mauricio; X Hong; N Anbazhagan; W Junhong, Cardolite US Patent US2016075805, 2016

This is a very interesting patent that discloses resins made from cashew nutshell liquid. These resins exhibit lower viscosity than the phenol-based homologs. They also exhibit good properties, which make them suitable additives as non-reactive diluents for solvent-free coating formulations; tackifiers for structural adhesive, pressure sensitive and hot-melt adhesives; stabilizers for lubricants, fuel and polymer formulations; plasticizers for thermoplastic polymers and processing aid for rubber compounding and stabilizers for respective rubber artifacts.

[100] L Don; D Adarsh; D Zhisheng; H Jinbao, Cardolite WO Patent 2008137706, 2007

[101] (**) A I Rahobinirina, M F Rakotondramanga, A Berlioz-Barbier, E Métay, V Ramanandraibe, M Lemaire, Tetrahedron Letters, 2017, 58, 2284-2289

[102] J E Mgaya, S A Bartlett, E B Mubofu, Q A Mgani, A M Z Slawin, P J Pogorzelec, D J Cole-Hamilton, Chem Cat Chem, 2016, 8, 751-757

[103] J E Mgaya, E B Mubofu, Q A Mgani, D B Cordes, A M Slawin, D J Cole-Hamilton, Eur. J. Lipid Sci. Tech, 2015, 117, 190-199

[104] L Kisula, S J M Mdachi, C de Koning, Q A. Mgani, Tanzania Journal of Science, 2015, $41,27-37$ 